\title{
ANALISIS USAHA SARANG BURUNG WALET \\ DIKELURAHAN TEMBILAHAN KOTA (Studi Kasus Usaha Sarang Burung Walet Pak Sutrisno)
}

\author{
Gunawan Syahrantau', M.Yandrizal1 \\ 1Program Studi Agribisnis Fakultas Pertanian UNISI
}

Email: syahrantau_gsr@yahoo.co.id

\begin{abstract}
ABSTRAK
Tujuan penelitian adalah untuk mengetahui besarnya biaya, penerimaan, keuntungan dan efisiensi usaha dari usaha sarang walet Pak Sutrisno di Kelurahan Tembilahan Kota.Metode analisis data yang digunakan dalam penelitian ini adalah analisi biaya, analisis penerimaan, analisis keuntungan dan analisis efisiensi usaha. Hasil penelitian menunjukkan bahwa : (1) Biaya total rata-rata yang dikeluarkan pada usaha Sarang Burung Walet Pak Sutrisno adalah sebesar Rp. 11.475.355,55,(2) rata - rata penerimaan yang diperoleh sebesar Rp.38.000.000,00 per bulan, (3) rata-rata keuntungan yang di peroleh sebesar Rp.26.524.644,45 per bulan, (4) Nilai efisiensi usaha adalah sebesar 3,31, yang berarti bahwa usaha Sarang Walet Pak Sutrisno sudah efisien, dimana setiap Rp1 biaya yang dikeluarkan akan mendapatkan penerimaan sebesar Rp.3,31 dan keuntungan Rp.2,31.
\end{abstract}

Kata Kunci : sarang walet, biaya investasi, keuntungan, efisiensi

\section{ABSTRACT}

The purposes of research were to determine the cost, revenue, profit and business efficiency of swallow's nest of Pak sutrisno in Subdistrict Tembilahan.The methods used are the total cost analysis, revenue, profit and analysis ofbusiness efficiency.The results showthat:(1) Average total cost is Rp11.475.355,55/month,(2)The averagerevenue is Rp38.000.000,00/month, (3) The average profit is Rp26.524.644,45/month, (4) The value $\mathrm{R} / \mathrm{C}$ ratio is 3,31, which means the effort of Swallow's Nest of Mr. Sutrisno efficient, where every one rupiah of cost spent will give revenue Rp3,31 and will give profit $\mathrm{Rp} 2,31$.

Keywords: swallow's nest, profit, efficiency

\section{PENDAHULUAN}

Salah satu komoditas agribisnis yang mempunyai peluang pasar besar terutama pasar ekspor dan mempunyai nilai ekonomi yang tinggi adalah sarang burung walet.Sarang burung walet merupakan salah satu makanan yang terkenal didunia.Sarang burung walet dipercaya memiliki manfaat yang sangat baik bagi kesehatan tubuh manusia.karena manfaatnya yang berkhasiat itu maka tidakheran jika harganya sangat mahal.

Usaha sarang burung walet sangat menjanjikan dan memiliki 
banyak tantangan, selain harus memiliki modal besar hingga ratusan juta rupiah, peternak harus pandai mengelola rumah walet agar tetap betah di huni oleh walet.Hasil dari peternakan walet adalah sarangnya yang terbuat dari air liurnya.Sarang walet ini selain mempunyai harga tinggi, juga dapat bermanfaat bagi dunia kesehatan, yaitu untuk menyembuhkan paru-paru, panas dalam, melancarkan peredaran darah dan penambah tenaga.

Salah satu usaha sarang burung walet yang cukup berkembang di kelurahan Tembilahan Kota adalah milik Pak Sutrisno. Usaha Walet ini di dirikan padatahun 1997. Usaha yang di dirikan oleh pak sutrisno ini berdasarkan saran dari keluarga di mana menganggap sarang burung walet merupakan usaha yang sangat menjanjikan di karenakan harga jual untuk perkilonya yang tinggi.

Pada tahun 2007 hingga tahun 2013 harga perkilo untuk sarang burung walet sangat bervariasi antara Rp9.000.000,00/kg sampai Rp15.000.000,00/kg tergantung dari kualitasnya. Untuk kualitas super (mangkok super) sarang yang paling bersih, warnanya sangat putih dan tidak ada bulu burung, mencapai harga Rp15.000.000,00/kg, kualitas A (mangkok) sarang yang terdapat bulu burung dan sedikit kotor, mencapai Rp13.000.000/kg, untuk kualitas B (sudut) sarang yang agak kotor dan tidak terbentuk seperti mangkok, mencapai Rp11.000.000,00/kg sedangkan untuk kualitas $\mathrm{C}$ sarang yang paling kotor sehingga harganya paling murah, mencapai Rp9.000.000,00/kg.Akan tetapi dari tahun 2014 sampai tahun 2016 sangat sulit mendapatkan kualitas A, karena disebabkan tingginya tingkat ancaman seperti Burung Hantu, Tikus dan Karlahut (Kebakaran Lahan Hutan) dimana asap kebakaran tersebut membuat walet tidak betah berada di rumah walet sehingga sarang walet tidak terbentuk sempurna.

Usaha Sarang Burung Walet milik Pak Sutrisno membutuhkan modal yang sangat besar seperti modal untuk mendirikan bangunan, namun dalam menjalankan usahanya ada yang berhasil dan ada juga yang gagal.Permasalahan yang lainnya adalah peternak belum mengetahui secara pasti biaya yang di keluarkan dikarenakan tidak melakukan pembukuan dan peternak tidak mengetahui secara rinci pendapatan yang di peroleh. Tujuan penelitian ini adalah untuk mengetahui besarnya biaya, penerimaan, keuntungan dan efisiensi usaha dari usaha sarang walet Pak Sutrisno di Kelurahan Tembilahan Kota.

\section{TINJAUAN PUSTAKA}

\subsection{Burung Walet (collocalia fuciphaga)}

Collocalia

fuciphaga

merupakan spesies dari burung walet yang paling banyak di budidayakan di Indonesia.Spesies ini berukuran sedang $(12 \mathrm{~cm})$, tubuh bagian atas berwarna coklat kehitam-hitaman dengan tungging abu-abu pucat, tubuh bagian bawah berwarna coklat, sayap berbentuk bulan sabit memanjang dan runcing, memiliki ekor yang menggarpu dan kuku yang tajam. Kedua jenis kelamin pada burung ini sulit di bedakan memiliki bobot tubuh 8,7-14,8 gram dan bentang sayap 110-118 mm, burung ini bersifat monogami dan induk 
betina menghasilkan dua butir telur yang dierami oleh kedua induk selama lebih kurang 23 hari (Wibowo. S, 2008)

Burung walet sarang putih memiliki klasifikasi zoologis sebagai berikut:

$\begin{array}{ll}\text { Kerajaan } & : \text { Animalia } \\ \text { Filum } & : \text { Chordata } \\ \text { Kelas } & : \text { Aves } \\ \text { Ordo } & : \text { Apodiformes } \\ \text { Famili } & : \text { Apodidae } \\ \text { Genus } & : \text { Collocalia } \\ \text { Spesies } & : \text { Collocalia fuciphaga }\end{array}$

Burung ini merupakan penerbang yang kuat, mampu terbang sekitar 40 jam secara terus menerus, menjalani home range dengan radius $25-40 \mathrm{~km}$. Burung walet memiliki ekholokasi sehingga mampu terbang di tempat yang gelap. Sarang Collocalia ficiphaga terbentuk dari air liur burung tersebut yang mengeras.

\subsection{Produksi Burung Walet}

Berdasarkan asal usulnya, sarang burung walet diklasifikasikan menjadi dua tipe, yaitu sarang burung walet gua (liar) dan sarang burung walet rumahan (diternakkan).Sarang burung walet gua di bangun oleh burung walet di gua dan tebing (biasanya ditemukan di dekat wilayah dengan banyak air, laut atau air terjun).Beberapa sarang burung walet mempunyai warna yang berbeda karena iklim alam, makan dan minuman burung walet tersebut.Burung walet yang diternakan membangun sarang mereka dirumah sarang burung walet yang dibuat sedemikian rupa untuk menyamai dengan kondisi lingkungan liar (gua) hanya saja rumah burung walet ini di jaga kebersihannya oleh para peternak.
Sarang burung walet yang didapat dari rumah peternakan ini lebih bersih dari kotoran serta bulu burung tersebut, sehingga proses pembersihan lebih mudah dan hasil sarang burung walet lebih putih.

Burung walet mempunyai kebiasaan meninggalkan sarang mereka pada pagi hari untuk mencari makan dan kembali pada sore hari untuk beristirahat atau memberi makan anak-anak mereka.Sarang burung dipanen 3 kali pertahun, dengan setiap periode panen umumnya berlangsung 3 bulan. Periode pertama adalah januari april, hal ini segera diikuti oleh periode kedua dan ketiga. Curah hujan sangat tinggi pada periode pertamaini membujuk dan lingkungan yang sangat cocok untuk pertumbuhan hewan kecil dan tanaman memberikan banyak walet makanan.Walet tumbuh sangat kuat dan dengan demikian menghasilkan jumlah berlebihan air liur.Sarang burung di panen selama periode ini adalah yang paling mahal karena sarang tersebut besar dan tebal, sangat bengkak dan mengandung kotoran lebih sedikit.Periode panen kedua adalah pada saat musim kemarau.Ada penurunan dalam pasokan makanan untuk burung walet dan ini memuncak dalam sarang brung yang tipis dan longgar dan benang sarang tebal.Bentuk dan kapasitas pembengkakkan sarang lebih miskin dari periode pertama.Periode ketiga adalah baik dalam musim kemarau.Sekresi air liur mereka rendah dan bulu terpisah.Sarang burung yang di bangun lebih kecil dalam ukuran, mengandung kotoran yang lebih besar (bulu) dan memiliki kapasitas pembengkakan sangat miskin. 


\subsection{Biaya}

Biaya adalah nilai dari semua masukan ekonomi yang di perlukan, yang dapat di perkirakan dan dapat di ukur untuk menghasilkan sesuatu produk (Prasetya, 1995).Menurut (Zulkifli,2010) Biaya tetap adalah biaya yang jumlahnya sampai tingkat kegiatan tertentu relatif tetap dan tidak terpengaruh oleh perubahan volume kegiatan.Biaya tetap merupakan jenis biaya yang bersifat statis (tidak berubah) dalam ukuran tertentu. Biaya ini akan tetap kita keluarkan meskipun kita tidak melakukan aktivitas apapun atau bahkan ketika kita melakukan aktivitas yang sangat banyak sekalipun.

Biaya total menurut Wahyu (2010) berarti seluruh biaya yang dikeluarkan oleh suatu perusahaan dalam memproduksi sejumlah output.Sedangkan menurut Samuelson dan Nordhaus (2003) Biaya Total merupakan penegluaran terendah yang diperlukan untuk memproduksi setiap tingkat output.

\subsection{Penerimaan}

Menurut Mailya (2009), semakin banyak jumlah produk yang dihasilkan maupun semakin tinggi harga per unit produk yang bersangkutan, maka penerimaan total yang diterima produsen akan semakin besar. Sebaliknya jika produk yang dihasilkan sedikit dan harganya rendah maka penerimaan total yang diterima oleh produsen semakin kecil.

Penerimaan adalah perkalian antara produksi yang dihasilkan dengan harga jual dan biasanya produksi berhubungan negatif dengan harga, artinya harga akan turun ketika produksi berlebihan (Soekartawi, 1995).

\subsection{Keuntungan}

Keuntungan (profit) adalah tujuan utama dalam pembukaan usaha yang direncanakan.Semakin besar keuntungan yang diterima, semakin layak usaha yang dikembangkan.Didasarkan pada perkiraan dan perencanaan produksi dapat diketahui pada jumlah produksi berapa perusahaan mendapat keuntungan dan pada jumlah produksi berapa pula perusahaan mendapat kerugian (Ibrahim, 2003).Keuntungan atau laba adalah menunjukkan nilai lebih (hasil) yang diperoleh dari modal yang dijalankan.

\subsection{Efisiensi Usaha}

Efisiensi usaha dapat diketahui dengan menghitung perbandingan antara besarnya penerimaan dan biaya yang digunakan dalam proses produksi yaitu dengan menggunakan $\mathrm{R} / \mathrm{C}$ Ratio (Return cost Ratio). R/C adalah perbandingan antara total penerimaan dengan biaya total. $\mathrm{R} / \mathrm{C}$ menunjukkan pendapatan kotor (penerimaan) yang diterima untuk setiap rupiah yang dikeluarkan untuk produksi

Soekartawi (1995).

\section{METODOLOGI PENELITIAN}

\subsection{Waktu dan Tempat Penelitian}

Penelitian ini telah dilaksanakan pada bulan Maret sampai dengan Mei 2017 pada usaha sarang burung walet Pak Sutrisno di Jalan Jendral Sudirman Kalurahan Tembilahan Kota, pemilihan lokasi dengan pertimbangan bahwa usaha 
sarang burung walet milik Pak Sutrisno merupakan salah satu usaha yang cukup berkembang di Kelurahan Tembilahan Kota.

\subsection{Metode Pengumpulan Data}

a. Observasi, yaitu dengan mengamati secara langsung objek penelitian sehingga dapat diperoleh gambaran yang nyata dari keadaan perusahaan.

b. Wawancara atau interview, yaitu dengan melakukan tanya jawab langsung dengan pimpinan dan karyawan yang memiliki informasi yang diperlukan.

\subsection{Tekhnik Analisis Data}

\subsubsection{Biaya (Cost)}

Biaya total menurut Wahyu (2010) berarti seluruh biaya yang dikeluarkan oleh suatu perusahaan dalam memproduksi sejumlah output.Sedangkan menurut Samuelson dan Nordhaus (2003) Biaya Total merupakan pengeluaran terendah yang diperlukan untuk memproduksi setiap tingkat output.Biaya Total dihitung dengan menggunakan rumus sebagai berikut:

$$
\mathrm{TC}=\mathrm{TFC}+\mathrm{TVC}
$$

Keterangan:

TC : Biaya Total Usaha (Rp) / Satu kali panen

TFC : Biaya Tetap Usaha (Rp) / Satu kali panen

TVC : Biaya Variabel Usaha (Rp) / Satu kali panen

Biaya penyusutan peralatan dihitung dengan metode garis lurus (Straight Line Metodh) dengan rumus sebagai berikut:

$$
\mathrm{D}=-
$$

Keterangan:

D = Nilai Penyusutan Alat

(Rp/Unit/Tahun)

$\mathrm{C}=$ Harga Beli Alat (Rp/Unit)

$\mathrm{SV}=$ Nilai Sisa Alat (Rp/Unit)

$20 \%$ dari nilai beli

UL =Masa Pakai Alat (Tahun)

\subsubsection{Penerimaan}

Penerimaan adalah perkalian antara produksi yang dihasilkan dengan harga jual dan biasanya produksi berhubungan negatif dengan harga, artinya harga akan turun ketika produksi berlebihan (Soekartawi, 1995). Penerimaan dapat dihitung dengan menggunakan rumus sebagai berikut :

$$
\mathrm{TR}=\mathrm{Q} \times \mathrm{P}
$$

Keterangan :

TR : Penerimaan Total usaha (Rp)/ Satu kali panen sarang burung walet

$\mathrm{P} \quad$ : Harga produk usaha (Rp) /

Satu kali panen sarang burung walet

Q : Jumlah produk usaha (Rp) /

Satu kali panen sarang burung walet

\subsubsection{Keuntungan}

Keuntungan (profit) adalah tujuan utama dalam pembukaan usaha yang direncanakan.Semakin besar keuntungan yang diterima, semakin layak usaha yang dikembangkan.Didasarkan pada perkiraan dan perencanaan produksi dapat diketahui pada jumlah produksi berapa perusahaan mendapat keuntungan dan pada jumlah produksi berapa pula perusahaan mendapat kerugian (Ibrahim, 2003).Keuntungan atau laba adalah menunjukkan nilai lebih (hasil) yang diperoleh dari modal yang dijalankan.Setiap kegiatan yang dijalankan perusahaan tentu 
berdasarkan modal yang dijalankan.Dengan modal itulah keuntungan atau laba diperoleh.Hal ini yang menjadi tujuan utama dari setiap perusahaan (Muhammad, 2005). Secara matematis dapat ditulis sebagai berikiut:

$$
\pi=\mathrm{TR}-\mathrm{TC}
$$

Keterangan :

$\pi=$ Keuntungan (Rp) / Satu kali panensarang burung walet $\mathrm{TR}=$ Total Penerimaan $(\mathrm{Rp}) /$ Satu kali panen sarang burung walet $\mathrm{TC}=$ Total Biaya (Rp)/ Satu kali panen sarang burung walet

\subsubsection{Efesiensi Usaha}

Efesiensi usaha dapat diketahui dengan menghitung perbandingan antara besarnya penerimaan dan biaya yang digunakan dalam proses produksi yaitu dengan menggunakan $\mathrm{R} / \mathrm{C}$ Ratio (Return cost Ratio). R/C adalah perbandingan antara total penerimaan dengan biaya total. $\mathrm{R} / \mathrm{C}$ menunjukkan pendapatan kotor (penerimaan) yang diterima untuk setiap rupiah yang dikeluarkan untuk produksi Soekartawi (1995). Secara matematis dapat ditulis sebagai berikut :

$$
\mathrm{RCR}=\frac{\mathrm{TR}}{\mathrm{TC}}
$$

Keterangan :

TR (Total Revenue) : Penerimaan (Rp) / Satu kali panen sarang burung walet

TC (Total Cost) : Biaya (Rp)/

Satu kali panen sarang burung walet

Kriteria yang digunakan dalam penentuan efisiensi usaha adalah :

TR/TC $>1$ berarti usaha yang dijalankan sudah efisien.
$\mathrm{TR} / \mathrm{TC}=1$ berarti usaha mencapai titik impas (BEP).

TR/TC $<1$ berarti usaha yang dijalankan tidak efesien.

\section{HASIL DAN PEMBAHASAN}

\subsection{Modal Usaha}

Pengertian Modal Usaha menurut Kamus Besar Bahasa Indonesia dalam Listyawan Ardi Nugraha (2011:9) "modal usaha adalah uang yang dipakai sebagai pokok (induk) untuk berdagang, melepas uang, dan sebagainya; harta benda (uang, barang, dan sebagainya) yang dapat dipergunakan untuk menghasilkan sesuatu yang menambah kekayaan".Modal dalam pengertian ini dapatdiinterpretasikan sebagai sejumlah uang yang digunakan dalam menjalankan kegiatankegiatan bisnis.Banyak kalangan yang memandang bahwa modal uang bukanlah segala-galanya dalam sebuah bisnis.

Dalam memulai usaha sarang burung walet, pengusaha membutuhkan modal untuk membeli peralatan maupun bahan-bahan yang dibutuhkan. Modal merupakan salah satu faktor penting dalam mendirikan usaha, tanpa modal yang mencukupi maka usaha yang dibangun tidak akan berjalan sebagaimana mestinya. Berdasarkan hasil penelitian, Sumber modal yang digunakan pengusaha secara keseluruhan pada usaha sarang burung walet ini merupakan modal pribadi dari tabungan.

\subsection{Peralatan Usaha}

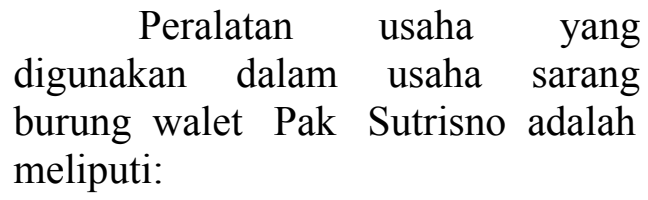


1. Skrap sebagai alat untuk memanen sarang burung walet

2. Lampu Senter Kepala berfungsi untuk penerangan pada saat memanen sarang burung walet

3. Tangga Aluminium berfungsi untuk tempat berpijak pada saat memanjat untuk memanen walet

4. Speaker berfungsi sebagai penghasilkan suara untuk memancing agar burung walet masuk kerumah walet

5. Flashdisc berfungsi sebagai alat penyimpan suara-suara burung walet

6. Aki GS berfungsi sebagai arus listrik cadangan

7. Mesin Air Sanyo berfungsi untuk menyedot air ke dalam bak penampungan pada rumah walet yang berguna sebagai tempat mandi burung walet

8. Ampli berfungsi untuk menyalurkan suara ke masingmasing speaker

9. Kabel berfungsi untuk penyambung arus dari ampli ke speaker.

\subsection{Produksi}

Proses produksi sarang burung walet dilakukan 1 kali dalam 1 bulan, proses pembentukan sarang burung walet berasal dari air liurnya, cairan tersebut bersifat lem yang akan mengeras dengan mangandung banyak komponen lain yang terlarut dalam kelenjar liur tersebut.Proses yang berlangsung terus menerus sampai memakan waktu 20 hari akan menghasilkan lembaran menyerupai belahan mangkok yang secara alami digunakan sebagai sarang bagi burung walet tersebut.

\subsection{Pemasaran}

Pemasaran adalah tindakantindakan yang diperlukan untuk menyampaikan barang produksi dari tangan produsen ketangan konsumen.Pemasaran sarang burung walet Pak Sutrisno di jual ke tempat pedagang pengumpul luar kota yang telah di tunjuk oleh pemerintah sebagai tempat yang resmi untuk di lakukan proses selanjutnya dan di ekspor ke luar negeri. Sistem pembayaran yang di lakukan pengumpul yaitu dengan cara transfer tunai. Pada proses pendistribusian ke luar kota, sarang burung walet yang akan dikirim menggunakan jasa pengiriman pos indonesia dengan tarif Rp100.000,$/ \mathrm{Kg}$.

\subsection{Analisis Usaha \\ 4.5.1 Analisis Biaya}

Menurut Mulyadi (2012), dalam arti luas biaya adalah pengorbanan sumber ekonomis yang diukur dalamsatuan uangyang telah terjadi atau mungkin terjadi untuk mencapai tujuan tertentu. Dalam arti sempit biaya merupakan bagian dari harga pokok yang dikorbankan dalam usaha untuk memperoleh penghasilan.Biaya dalam penelitian ini adalah seluruh biaya yang dikeluarkan untuk proses produksi sarang burung walet, baik biaya yang dikeluarkan atau tidak dikeluarkan. Biaya tersebut terdiri dari biaya tetap dan biaya variabel.

\section{a. Biaya Tetap}

Biaya tetap adalah biaya yang jumlahnya tidak berubah, terlepas dari perubahan tingkat aktivitas dalam kisaran relevan tertentu. Biaya tetap akan terus saja dikeluarkan walaupun tingkat keluaran pabrik 
anjlok hingga titik nol (Simamora, 2002).Biaya tetap dalam usaha sarang burung walet Pak Sutrisno meliputi biaya penyusutan peralatan, biaya tenaga kerja dan bangunan.Jumlah biaya tetap dapat dilihat pada Tabel 1.

Tabel 1. Rata-rata Biaya Tetap Usaha Sarang Burung Walet Pak Sutrisno Perbulan

\begin{tabular}{clrr}
\hline No & Jenis Biaya Tetap & Jumlah (Rp) & \multicolumn{1}{c}{$\begin{array}{c}\text { Persentase } \\
(\%)\end{array}$} \\
\hline 1 & Penyusutan Peralatan & $570.022,22$ & 5,61 \\
2 & Tenaga Kerja & $7.500 .000,00$ & 73,87 \\
3 & Bangunan & $2.083 .333,33$ & 20,52 \\
\hline & Total & $10.153 .355,55$ & 100,00
\end{tabular}

Sumber: Data primer 2017

Tabel 1 diatas menunjukkan bahwa sumber biaya tetap terbesar berasal dari biaya tenaga kerja yaitu sebesar Rp7.500.000,00 per bulan atau 73,87 persen tiap satu kali produksi upah untuk 3 orang tenaga kerja yaitu masing-masing tenaga kerja mendapatkan upah sebesar Rp2.500.000,00/bulan. Semua karyawan berjenis kelamin lakilakidan semuanya belum berkeluarga/menikah.

Kemudian biaya bangunan sebesar Rp2.083.333,33,-per bulan atau 20,52 persen. Biaya bangunan ini sebenarnya tidak benar-benar dikeluarkan dikarenakan dalam proses produksi sarang burung walet adalah merupakan bangunan milik sendiri. Tetapi dalam penelitian ini menggunakan konsep keuntungan sehingga biaya bangunan tetap diperhitungkan.Bangunan ini didirikan sejak awal usaha ini di buka yaitu tahun 1997 jadi usaha ini berdiri sudah cukup lama.

Selanjutnya biaya yang terkecil adalah biaya penyusutan peralatan sebesar Rp570.022,22,- per bulan atau 5,61 persen. Biaya penyusutan peralatan ini juga tidak benar-benar dikeluarkan.Perhitungan biaya tetap dapat dilihat pada lampiran 2,3 dan 4.

Hal ini senada dengan penelitian Robins (2009), yang menunjukkan bahwa persentasi terbesar berasal dari biaya tenaga kerja yaitu sebesar Rp4.000.000,00 perbulan atau 69,69 persen. Kemudian biaya Penyusutan peralatan yaitu sebesar Rp1.190.000,00 perbulan atau 20,73 persen. Selanjutnya biaya yang paling terkecil adalah biaya bangunan yaitu sebesar Rp550.000,00 perbulan atau 9,58 persen.

\section{b. Biaya Tidak Tetap}

Suprapto (2005), biaya variabel (Variable cost) adalah biaya yang jumlah totalnya berubah secara sebanding (proporsional) dengan perubahan volume kegiatan atau biaya yang dikeluarkan oleh pengusaha sebagai akibat penggunaan factor produksi variabel, sehingga biaya ini besarnya berubahubah dengan berjumlahnya barang yang dihasilkan.Komposisi biaya variabel dapat dilihat pada Tabel 2 . 
Tabel 2. Rata-rata Biaya Tidak Tetap Usaha Sarang Burung Walet Pak Sutrisno Perbulan

\begin{tabular}{llrr}
\hline No & \multicolumn{1}{c}{ Jenis biaya tidak tetap } & Jumlah (Rp) & Persentase (\%) \\
& & & \\
\hline 1 & Bahan Penolong & $10.000,00$ & 0,76 \\
2 & Pengemasan & $42.000,00$ & 3,18 \\
3 & Lain-lain & $1.270 .000,00$ & 96,07 \\
\hline \multicolumn{2}{r}{ Total } & $1.322 .000,00$ & 100,00 \\
\hline
\end{tabular}

Sumber: Data primer 2017

Tabel 2 menunjukkan bahwa pada usaha sarang burung walet pak sutrisno tidak menggunakan bahan baku, jadi biaya tidak tetap pada usaha sarang burung walet tersebut hanya meliputi bahan penolong,pengemasan dan biaya lain-lain. Dalam satu bulan bahan penolong yang digunakan pengusaha adalah pakan walet $1 \mathrm{~kg}$ dengan harga Rp10.000,- per kg. Pengemasan digunakan kardusbesarsebanyak 2 Pcs dengan harga Rp10.000,-/Pcs, dan lakban sebanyak 1 rol dengan harga Rp12.000,-/rol kemudian air aqua ukuran 1,5L sebanyak 1 botol dengan harga Rp10.000,-/botol, Biaya lain-lain seperti biaya pengiriman sebanyak $4 \mathrm{Kg} /$ bulan dengan hargaRp 100.000,-/bulan, surat jalan sebanyak $4 \mathrm{Kg} /$ bulan sebesar Rp5.000,-/Kg, surat pemeriksaan dengan harga Rp150.000,-/satu kali pengiriman dan listrik selama 1 bulan sebesar Rp700.000,-.Perhitungan biaya tidak tetap dapat di lihat pada lampiran 5.

Brotodiharjo

(2005), memperlihatkan bahwa persentasi terbesar berasal dari biaya lain-lain yaitu sebesar Rp2.150.000,00 perbulan atau 97,05 persen.
Kemudian biaya pengemasan yaitu sebesar Rp50.000,00 perbulan atau 2,26 persen. Selanjutnya biaya yang paling terkecil adalah biaya bahan penolong yaitu sebesar Rp15.344,00 perbulan atau 0,69 persen. Sehingga pada usaha sarang burung walet pak Sutrisno dan pada penelitian Brotodiharjo dapat dikatakan senada karena biaya tidak tetap terbesar sama-sama berasal dari biaya lainlain, dan biaya tidak tetap terkecil berasal dari biaya bahan penolong.

\section{c. Biaya Total}

Biaya total menurut Wahyu (2010)berarti seluruh biaya yang dikeluarkan oleh suatu perusahaan dalam memproduksi sejumlah output.Sedangkan menurut Samuelson dan Nordhaus (2003) Biaya Total merupakan pengeluaran terendah yang diperlukan untuk memproduksi setiap tingkat output.

Biaya total usaha sarang burung walet meliputi seluruh biaya tetap dan biaya variabel. Besarnya biaya total usaha sarang burung walet dalam satu kali proses produksi/bulan dapat dilihat pada Tabel 3. 
Tabel 3. Rata-rata Biaya Total Pada Usaha Sarang Burung Walet Pak Sutrisno Perbulan

\begin{tabular}{ccrr}
\hline No & Jenis Biaya Total & Jumlah (Rp) & Persentase (\%) \\
\hline 1 & Biaya Tetap & $10.153 .355,55$ & 88,48 \\
2 & Biaya Variabel & $1.322 .000,00$ & 11,52 \\
\hline & Total & $11.475 .335,55$ & 100,00 \\
\hline
\end{tabular}

Sumber: Data primer 2017

Tabel 3 menunjukkan bahwa biaya total pada usaha sarang burung walet Pak Sutrisno adalah sebesar Rp11.475.335,55 per Bulan. Dimana kontribusi terbesar barasal dari biaya tetap yaitu sebesar Rp10.153.355,55 per bulan atau 88,48 persen. Hal ini disebabkan komponen biaya tetap lebih banyak dibandingkan biaya tidak tetap sehingga biaya tetap yang dikeluarkan lebih besar, sedangkan biaya tidak tetap usahasarang burung walet hanya sebesar Rp1.322.000,00 per bulan atau 11,52 persen.

Hal ini senada pada penelitian Robins (2009), yang memperlihatkan bahwa persentase terbesar terdapat pada biaya tetap yaitu 69,66 persen atau sebesar Rp5.740.000,00 per bulan sedangkan persentase pada biaya tidak tetap yaitu 30,34 persen atau sebesar Rp2.500.000,00 per bulan. Hal ini karena jumlah biaya tetap lebih banyak dibandingkan biaya tidak tetap dan menyebabkan biaya yang dikeluarkan untuk memenuhi kebutuhan biaya tetap juga besar.

\subsubsection{Analisis Penerimaan dan Keuntungan}

Penerimaan adalah perkalian antara produksi yang dihasilkan dengan harga jual dan biasanya produksi berhubungan negatif dengan harga, artinya harga akan turun ketika produksi berlebihan (Soekartawi, 1995) dan Keuntungan (profit) adalah tujuan utama dalam pembukaan usaha yang direncanakan.Semakin besar keuntungan yang diterima, semakin layak usaha yang dikembangkan.Besarnya penerimaan dan keuntungan pada usaha sarang burung walet Pak Sutrisno dapat dilihat pada tabel 4 .

Tabel 4. Rata-rata Penerimaan dan Keuntungan Pada Usaha Sarang Burung Walet Pak Sutrisno

\begin{tabular}{clrr}
\hline No & & Uraian & \multicolumn{1}{l}{ Jumlah } \\
\hline 1 & Penerimaan & $38.000 .000,00$ \\
2 & Total Biaya & $11.475 .355,55$ \\
\hline 3 & Keuntungan & $26.524 .644,45$ \\
\hline
\end{tabular}

Sumber: Data Primer 2017

Tabel 4 menunjukkan bahwasarang burung walet yang dihasilkan selama 1 kali produksi adalah sebanyak $4 \mathrm{~kg}$ dengan harga Rp9.500.000,00 per bulan. Sehingga penerimaan yang di peroleh pengusaha sarang burung walet adalah sebesar Rp38.000.000,00 per bulan. Sedangkan total biaya yang dikeluarkan adalah sebesar 
Rp11.475.355,55 per bulan. Sehingga keuntungan yang diperoleh pengusaha adalah sebesar Rp26.524.644,45 per bulan. Sarang burung walet yang dihasilkan di hitung secara Ramas ( Kualitas Campur antara kualitas A,B dan C ) dengan harga yang sudah di tetapkan berdasarkan kerjasama antara peternak dan produsen.Perhitungan penerimaan dan keuntungan dapat di lihat pada lampiran 7.

\section{Robins}

(2009), memperlihatkan bahwa total penerimaan yang diperoleh pengusaha adalah sebesar Rp 24.382.580,97 per bulan, sedangkan total biaya yang dikeluarkan pengusaha adalah sebesar Rp $8.240 .000,00$ per bulan sehingga keuntungan yang diperoleh pengusaha adalah sebesar Rp 16.142.580,97 per bulan.

\subsubsection{Analisis Efisiensi Usaha}

Efesiensi usaha dapat diketahui dengan menghitung perbandingan antara besarnya penerimaan dan biaya yang digunakan dalam proses produksi yaitu dengan menggunakan $\mathrm{R} / \mathrm{C}$ Ratio (Return cost Ratio). R/C adalah perbandingan antara total penerimaan dengan biaya total. $\mathrm{R} / \mathrm{C}$ menunjukkan pendapatan kotor (penerimaan) yang diterima untuk setiap rupiah yang dikeluarkan untuk produksi Soekartawi (1995).Efisiensi usaha sarang burung walet Pak Sutrisno dapat dilihat pada tabel 5.

Tabel 5. Rata-rata Analisis Efisiensi Usaha Pada Usaha Sarang Burung Walet Pak Sutrisno per bulan

\begin{tabular}{clr}
\hline No & \multicolumn{1}{c}{ Uraian } & Jumlah (Rp) \\
\hline 1 & Total Penerimaan & $38.000 .000,00$ \\
2 & Total Biaya & $11.475 .355,55$ \\
\hline & Efisiensi Usaha (RCR) & 3,31 \\
\hline
\end{tabular}

Sumber: Data Primer 2017

Berdasarkan tabel 5, dapat diketahui bahwa nilai efisiensi usaha pada usaha sarang burung walet Pak Sutrisno adalah sebesar 3,31 yang berarti usaha sarang burung walet Pak Sutrisno yang telah dijalankan sudah efisien karena nilai $\mathrm{R} / \mathrm{C}>1$, Berarti setiap Rp1 biaya yang dikeluarkan dalam usaha sarang burung walet Pak Sutrisno akan menghasilkan penerimaan sebesar Rp3,31 dan keuntungan sebesar Rp2,31. Penelitian Brotodiharjo (2005), menunjukkan bahwa nilai efisiensi usaha pada usaha sarang burung walet di Kota Banjar Masin adalah sebesar 1,94.
Sehingga dapat disimpulkan bahwa pada penelitian usaha sarang burung walet Pak Sutrisno nilai RCR lebih besar, hal ini disebabkan karena besarnya penerimaan yang didapat oleh pengusaha yaitu sebesar Rp38.000.000,00 per bulantetapi biaya total yang dikeluarkan oleh pengusaha sarang burung walet sedikityaitu sebesar Rp11.475.335,55 per bulan. Maka diperoleh keuntungan sebesar Rp26.524.644,45 per bulan, sehingga usaha sarang burung walet Pak Sutrisno menghasilkan nilai RCR yaitu sebesar 3,31. Sedangkan pada penelitian Brotodiharjo (2005), penerimaan yang dihasilkan 
pengusaha sedikit yaitu Rp20.000.000,00 per bulan namun biaya total yang dikeluarkan besar yaitu Rp10.315.344,00 per bulan, maka pengusaha memperoleh keuntungan sebesar Rp9.684.656,00 per bulan sehingga nilai RCR pada usaha sarang burung walet di Kota Banjar Masin adalah sebesar 1,94.

\section{KESIMPULAN DAN SARAN}

\subsection{Kesimpulan}

1. Biaya Total yang di keluarkan pada Usaha Sarang Burung Walet Pak Sutrisno adalah sebesar Rp11.475,355,55, sedangkan penerimaan yang di dapat adalah sebesar Rp38.000.000, sehingga Keuntungan yang diperoleh dari usaha sarang burung walet Pak Sutrisno di Kelurahan Tembilahan Kota ini adalah sebesar Rp26.524.644,45,- untuk sekali produksi per bulan.

2. Usaha sarang burung walet Pak Sutrisno di Kelurahan Tembilahan Kota Kabupaten Indragiri Hilir mempunyai nilai efisiensi lebih dari satu $(\mathrm{R} / \mathrm{C}>1)$ yaitu sebesar 3,31. Hal ini berarti bahwa setiap Rp1,- biaya yang dikeluarkan pengusaha pada awal kegiatan usaha akan mendapatkan penerimaan sebesar Rp 3,31 dan keuntungan sebesar Rp 2,31

\subsection{Saran}

1. Untuk meningkatkan keuntungan,proses pengolahan atau pembersihansarang burung walet sebaiknya dapat dilakukan langsung di Tembilahantanpa harus melakukan pengiriman ke luar Kota.

2. Bangunan yang ada di bawah Sarang Burung Walet sebaiknya di gunakan untuk aktifitas usaha lainnya guna menambah pendapatan.

\section{DAFTAR PUSTAKA}

Austin, J.E. 1981. Agroindustrial Project Analysis. The John Hopkins University Press. London.

Borror, D. J. 2005. Pengenalan Pelajaran Serangga. Edisi keenam.Yogyakarta. Gajah Mada Perss. 825-826.

Brotodiharjo. R. 2005.Analisis Usaha Sarang Burung Walet Di Kota Banjar Masin, Skripsi. Universitas Sebelas Maret Surakarta : Surakarta.

Charles, F. 2001. Budidaya Rumah dan Sarang Walet. Surabaya. Gitamedia Perss.

DR payaman simanjuntak, 2008 Ekonomi Sumber Daya Manusia. Penebar swadaya. Jakarta.

Francis. 1987. The Management of EdibleBird's Nest Caves in Sabah Wildlife Section. Sabah Forest Departement, Sabah.

Hakim.A.

2011.Karakteristik Lingkungan Rumah dan Produksi Sarang Burung Walet (Collocalia Fuciphaga) di Kecamatan Haurgeulis, Kabupaten Indramayu, Jawa Barat.Skripsi.Institut Pertanian Bogor. Bogor. 